\title{
Sacral Fistula
}

National Cancer Institute

\section{Source}

National Cancer Institute. Sacral Fistula. NCI Thesaurus. Code C118308.

A pathologic communication between the skin and the dural space that is located 5-25

$\mathrm{mm}$ from the anal verge. 